\title{
APLIKACE TEXTURNÍ RTG-DIFRAKČNÍ ANALÝZY V TEKTONICE - KVANTIFIKACE PŘEDNOSTNÍ ORIENTACE KALCITU V KARBONÁTOVÝCH HORNINÁCH
}

\author{
Application of texture x-ray diffraction analysis in tectonic - an example of calcite preferred \\ orientation quantification in carbonate rocks
}

\author{
Stanislav Kurdík ${ }^{1}$, Rostislav Melichar', Jiří Novák ${ }^{2,3}$, Dalibor Všianský ${ }^{1}$ \\ 'Ústav geologických věd, Prírodovědecká fakulta, Masarykova univerzita, Kotlářská 2, 61137 Brno; e-mail: st.kurdik@gmail.com \\ 2 Ústav fyziky kondenzovaných látek, Př́rodovědecká fakulta, Masarykova univerzita, Kotlářská 2, 61137 Brno \\ ${ }^{3}$ CEITEC - Středoevropský technologický institut, Masarykova univerzita, Kamenice 753/5, 62500 Brno
}

Key words: texture $x$-ray diffraction analysis, tectonic, calcite, preferred orientation, pole figures

\begin{abstract}
The goal of this work was to apply texture $x$-ray diffraction analysis to study naturally strained rocks, in which the quantification of main preferred orientation cannot be conducted by the optical methods. This method has mainly been developed for metallography and its application in geology has been very limited so far. Samples of the fine-grained limestone have been collected from an outcrop, in which the direction of tectonic movement has been known. Thus, the tectonic situation could be correlated with the data obtained by XRD texture analysis. Analyses have been done by two devices with different geometry of experiment. The first experiment (Schulz reflection geometry) needed correction for the gain data, because of tilting of the sample, which led to the misalignment of the sample from the $x$-ray beam direction. The second one (in-plane geometry) has been measured, when the sample has been fixed and rotated, thus the correction was not needed. The results in a form of pole figures reflect the mechanism of deformation. The orientation of cleavage planes of calcite parallel to foliation indicates a cataclastic flow. Thus, the method could be used to study deformation mechanisms. The asymmetry of the results can show sense of shear, but it could also reflect inhomogenities of the samples.
\end{abstract}

Úvod

Texturní rentgenová (RTG) difrakční analýza je metoda, pomocí které lze identifikovat a kvantifikovat přednostní orientaci krystalitů, a to i minerálů submikroskopických nebo opticky izotropních. Metodika určování přednostní orientace minerálů pomocí RTG-difrakce a první experimenty byly prováděny v roce 1920, kdy Gross (1920) uveřejnil jednu $\mathrm{z}$ prvních studií o studiu monokrystalů Laueho metodou, přičemž uvažoval i o jejich orientaci $\mathrm{v}$ prostoru a záměrně ji měnil. $\mathrm{V}$ následujících letech publikovala řada autorů údaje o modifikacích Laueho metody pro stanovení prostorové orientace krystalitů. Zpravidla se jednalo o kovy. Významnou byla práce Wevera (1924) tím, že autor použil pro studium přednostní orientace zrn hliníku a železa v utvářených materiálech nejen Laueho metodu, ale i modifikaci Debye-Scherrerovy metody užívané ke studiu polykrystalických materiálů. Přednostní orientace se zde projevila nestejnoměrným vyhasínáním difrakčních kružnic na registračním filmu. Teprve v roce 1930 se objevily práce, $\mathrm{v}$ nichž byla tato výzkumná metoda aplikována na řešení petrografických a mineralogických problémů. Studium hornin však bylo v dřívějších dobách náročné. Příprava cylindrického vzorku (používaného kvůli geometrii difrakčního experimentu) byla technicky obtížná, a u méně soudržných hornin prakticky nemožná. Tyto aparatury byly principiálně určeny především pro registraci vyšších úhlů $2 \theta$, což je vhodné pro studium kubických krystalů, proto se tato metoda dále vyvíjela zejména $\mathrm{v}$ metalografii. $\mathrm{V}$ pozdějších letech byly horninové vzorky měřeny více transmisními metodami, kdy byla zapotřebí destička dostatečně tenká na prosvícení vzorku
(0,1-0,3 mm). U reflexních metod musely být prováděny korekce na geometrii vzorku (Schmidt 1975).

Od poloviny 20. století se používaly přímé registrace záření detektorem namísto registrace na film (zůstal pouze u některých speciálních metod) a výsledky byly uváděny ve formě konturových diagramů (napr. Schmidt 1975). V šedesátých a sedmdesátých letech dvacátého století prováděli v Československu rentgenografická měření pro studium hornin Schmidt a Štelcl. Pro svá měření zkonstruoval Schmidt vlastní goniometr. Př́stroj byl testován a využit na vzorcích z okolí brněnského masivu (Štelcl et al. 1980). I dnes vychází metodika RTG-difrakční texturní analýzy z poznatků metalografie. V geologickém výzkumu je obvykle aplikována méně často, a tak je účelem této práce ověřit použitelnost dané metody se současnými možnostmi př́ístrojů.

\section{Metodika \\ Odběr a príprava vzorků}

Pro studium byly odebírány orientované vzorky kalcitického vápence číslované ( 1 až 4 ). Orientace vzorků byla určována geologickým kompasem. Zároveň byly změřeny orientace deformačních foliací ve vápencích. $Z$ vybraných vzorků byly zhotoveny preparáty. Ze vzorku č. 1 byl připraven krytý výbrusový preparát pro petrografická pozorování pomocí polarizačního mikroskopu Olympus BX 51. Pro samotnou texturní analýzu byly použity vzorky 1 a 4 . Jednalo se o stejnou horninu, rozdíly ve vzorcích měly tedy být v pozici na výchoze a tedy v možné orientaci krystalů. Byly nařezány na destičky, jejichž orientace byla zvolena podle deformačních souřadnic $x, y, z$. Plochy destiček byly 
orientovány podél ploch foliace (kolmo na osu $z$ ), delší strana destičky ve směru lineace (osa $x$ ).

\section{RTG-difraktometrie}

Veškerá měření byla prováděna na difraktometru SmartLab společnosti Rigaku se stacionární měděnou anodou $\left(\lambda_{\mathrm{Ka}}=0,15418 \mathrm{~nm}\right)$. Použité napětí bylo př̀i měření $\mathrm{v}$ rovině (in-plane) $45 \mathrm{kV}$ a proud $200 \mathrm{~mA}$. U ostatních měření bylo napětí $40 \mathrm{kV}$ a proud $30 \mathrm{~mA}$.

Před vlastní texturní analýzou byla leštěná destička ze vzorku č. 4 analyzována na Ústavu fyziky kondenzovaných látek PřF MU při konvenční Brag-Brentano parafokusační geometrii přístroje $\mathrm{v}$ rozmezí od $20^{\circ}$ do $60^{\circ} 2 \theta$ s krokem $0,05^{\circ} / \mathrm{s} 2 \theta$.

Dále proběhly dvě série měření vzorků číslo 1 a 4 . Vzorek č. 4 byl měřen pomocí Schulzovy reflexní geometrie, vzorek č. 1 byl měřen geometrií v rovině (in-plane). Vzorky byly do přístroje vkládány tak, aby deformační osy $x, y, z$ souhlasily s hlavními osami př́stroje, což umožnilo jednodušší interpretaci výsledků bez nutnosti dodatečné rotace výsledných dat.

\section{Schulzova reflexní geometrie}

Měření přednostní orientace vybraných krystalografických ploch kalcitu probíhalo reflexní metodou, kdy byl difrakční úhel $2 \theta$ fixován v pozici odpovídající Braggovu úhlu těchto rovin. Intenzity difrakce byly zaznamenávány ve dvou proměnlivých úhlech, a to úhlu náklonu $\alpha$ difrakční roviny vzhledem $\mathrm{k}$ normále (kolmice odpovídající deformační ose $z$ ) $\mathrm{k}$ normále $\mathrm{k}$ povrchu vzorku a úhlu rotace $\beta$ vzorku taktéž kolem normály. Změna úhlu $\alpha$ byla realizována náklonem vzorku okolo horizontální osy, zatímco difrakční rovina určená polohou detektoru a zdroje záření byla orientována stále vertikálně. Jednotlivé intenzity pro dané úhly byly zobrazovány ve stereografické projekci jako pólové obrazce. Střed pólového obrazce byl definován pro úhel náklonu $\alpha=0^{\circ}$ a pro okraj je $\alpha=90^{\circ}$. Úhel $\alpha=0^{\circ}$ odpovídá orientaci, při níž je normála difraktujících krystalových rovin paralelní s normálou plochy vzorku a $\alpha=90^{\circ}$ znamená, že normála krystalové plochy je paralelně s povrchem vzorku. Úhel rotace má hodnotu $\beta=0^{\circ} \mathrm{v}$ horní ćásti diagramu a stoupá ve směru proti pohybu hodinových ručiček (Nagao - Kagami 2011). První série analýz proběhla na Ústavu fyziky kondenzovaných látek PřF MU, kdy byl měřen vzorek č. 4. Byla použita Schulzova reflexní geometrie přístroje s paralelním svazkem. Všechny roviny byly měreny s krokem $3^{\circ}$, a to $\mathrm{v}$ rozsahu $0^{\circ}<\alpha<90^{\circ}$ a $0^{\circ}<\beta<360^{\circ}$, rychlostí $3^{\circ} / \mathrm{min}$.

\section{Korekce defokusační chyby}

$\mathrm{V}$ průběhu měření byla zjištěna defokusační chyba při extrémních náklonech vzorku. Tato chyba byla popsána už dř́ve (Nagao - Kagami 2011). Pro opravu chyby, ke které docházelo $\mathrm{v}$ průběhu měření při náklonu vzorku, byly naměřeny difrakční intenzity odrazů práškového vzorku bez přednostní orientace. Byl použit prášek křemene, který je neštěpný, aby byla minimalizována možnost přednostní orientace. Bylo měřeno pomocí Schulzovy reflexní geometrie př́stroje $\mathrm{s}$ fokusačním zrcadlem a vzorek tak byl ozařován rovnoběžným svazkem. Všechny roviny byly měřeny s krokem $5^{\circ}$, a to $\mathrm{v}$ rozsahu $0^{\circ}<\alpha<80^{\circ}$ a $0^{\circ}$ $<\beta<360^{\circ}$ rychlostí $5^{\circ} / \mathrm{min}$. Korekce defokusační chyby byla provedena vydělením intenzit studovaného vzorku intenzitami práškového vzorku, což bylo přímo výstupem programu na vyhodnocování pólových obrazců.

\section{Měření geometrie v rovině (in-plane)}

Měření probíhalo při konstantním difrakčním úhlu 20. Náklon $\alpha$ byl pro toto měření realizován kombinací změny úhlu dopadu záření (tedy pohybem ramene detektoru), úhlu detektoru nad povrchem vzorku a rotací ramene detektoru okolo osy kolmé na povrch vzorku, jehož povrch byl fixován $\mathrm{v}$ horizontální poloze. Úhel rotace $\beta$ okolo normály k povrchu vzorku byl shodný s měřením v Schulzově reflexní geometrii. To umožnilo konstruovat kompletní pólový diagram od $\alpha=0^{\circ}$ po $\alpha=90^{\circ}$ bez nutnosti vzorek naklánět, a tím byla odstraněna defokusační chyba. Zářivý tok z RTG-lampy tak byl efektivněji využíván, nebot čárové ohnisko bylo po celou dobu paralelní s povrchem vzorku.

Druhá série měření proběhla ve výzkumném centru CEITEC. Analyzován byl vzorek č. 1. Geometrie př́stroje byla v rovině (in-plane) s paralelním RTG-svazkem. Intenzity difraktovaného svazku byly měřeny pro různé orientace strukturních rovin s krokem $3^{\circ}$, a to $\mathrm{v}$ rozsahu $0^{\circ} \leq \alpha \leq 90^{\circ}$ a $0^{\circ} \leq \beta<360^{\circ}$ rychlostí $3^{\circ} / \mathrm{min}$. Byly zjištovány orientace stejných rovin jako v první sérii (Schulzovou reflexní geometrií). Na difrakčním záznamu se úhlová pozice lišila (viz tab. 1).

Tab. 1: Pozice úhlu $2 \theta \mathrm{z}$ databáze pro analyzované krystalografické roviny jsou zapsány Millerovými indexy, pozice difrakčních maxim jsou $\mathrm{v}$ jednotkách $2 \theta$ a mezirovinná vzdálenost je $\mathrm{v}$ ångstromech.

Tab. 1: Position of $2 \theta$ angle from database for analyzed crystallographic planes are shown as Miller indices, positions of maximum intensities are shown in $2 \theta$ degrees and spacing of planes is in ångstroms.

\begin{tabular}{|c|c|c|}
\hline indexy $(\mathrm{h} \mathrm{k} \mathrm{l})$ & pozice $\left[{ }^{\circ} 2 \theta\right]$ & mezirovinná vzdálenost $[\AA]$ \\
\hline$\left(\begin{array}{llll}1 & 0 & 4\end{array}\right)$ & 29,390 & 3,037 \\
\hline$\left(\begin{array}{lll}0 & 1 & 8\end{array}\right)$ & 47,486 & 1,913 \\
\hline$\left(\begin{array}{llll}1 & 1 & 3\end{array}\right)$ & 39,396 & 2,285 \\
\hline$\left(\begin{array}{lll}0 & 0 & 6\end{array}\right)$ & 31,422 & 2,845 \\
\hline$\left(\begin{array}{llll}2 & 0 & 2\end{array}\right)$ & 43,145 & 2,095 \\
\hline
\end{tabular}

\section{Výstup z měření}

Naměřená data byla programem 3D Explore vyobrazena jako pólové obrazce, což jsou stereografické projekce na horní polokouli, kde jsou v dvourozměrném řezu vyobrazeny osy TD (transverse direction) a RD (rolling direction). V kontextu s deformačními osami vzorků je $x$ rovnoběžné $\mathrm{s} \mathrm{TD}, y$ je rovnoběžné $\mathrm{s} \mathrm{RD}$ a $z$ je kolmé na obrazec.

\section{Materiál}

Vzorky byly odebrány v okolí obce Vavřinec-Veselice (N 49²4'04.8" E 16²42'28.6"), v mapovém listu 1: 50 000, list 24-23 Protivanov (viz obr. 1), asi 20 metrů od sebe a mají podobnou orientaci ve výchoze. Lokalita leží v mo- 


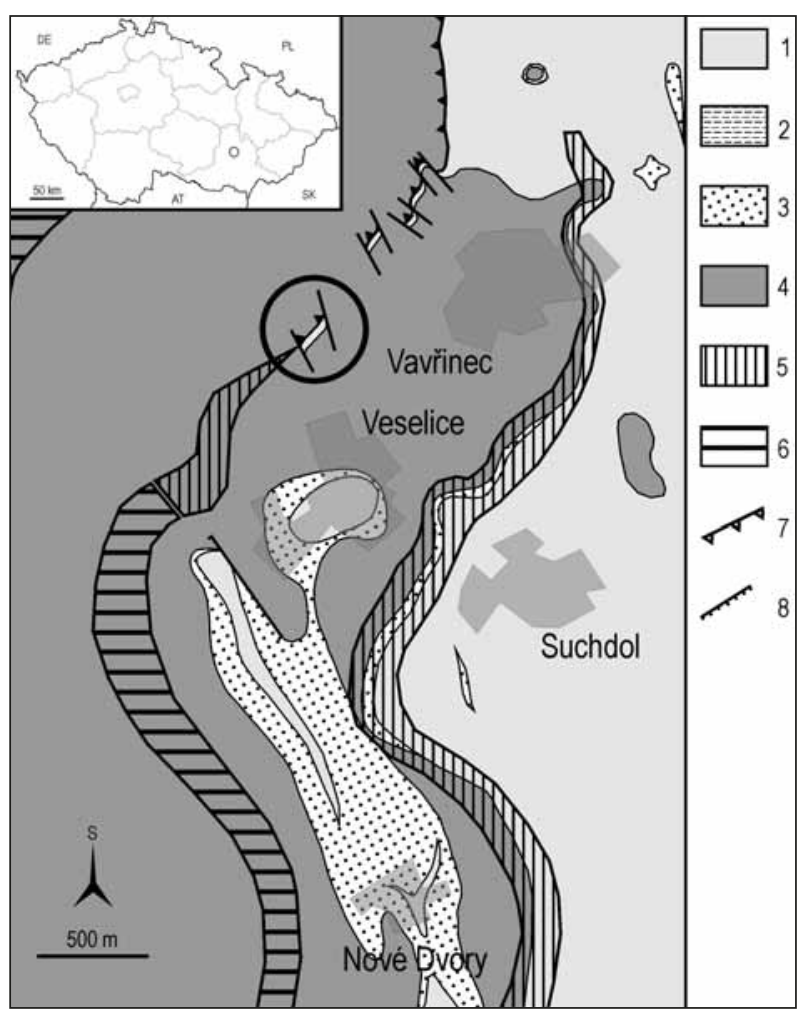

Obr. 1: Mapové schéma s vyznačením místa odběru kruhem: 1 - devonské vápence; 2 - petrovické břidlice; 3 - devonská bazální klastika; 4 - granitoidy brněnského masivu; 5 - oblasti na povrch vystupujících násunových ploch; 6 - oblasti předpokládaných násunových ploch vystupujících na povrch; 7 - násun; 8 - zlom (podklad Marhanský 2014).

Fig. 1: Map with the sampling point marked by a ring: $1-$ Devonian limestone; 2 - Petrovice slate; 3 - Devonian basal clastic; 4 - granitoids of Brno massif; 5 - outcrops of thrust zones; 6 - presumed outcrop of thrust zone; 7 - slide; 8 - fault (based on Marhanský 2014).

ravskoslezské oblasti, konkrétně v brněnském masivu, kde je severozápadně od zmíněné obce $\mathrm{v}$ granitoidech brněnského masivu tektonická šupina devonských vápenců, které patří k platformnímu vývoji moravskoslezského devonu. Devonské kalcitické vápence na výchozech jsou silně deformované mechanismem jednoduchého střihu, mají vyvinutou výraznou deformační foliaci, která je místy vrásněna sevřenými vrásami. Foliace má dominantní směr SSV-JJZ s mírným úklonem k ZSZ (310/40). Dřívější studia ukázala smysl pohybu nadloží podle porfyroklastových systémů s tlakovými stíny k SSV. Okolní granitoidy jsou silně chloritizovány, což implikuje deformaci v podmínkách facie zelených břidlic s teplotami kolem $300^{\circ} \mathrm{C}$ (Marhanský 2014).
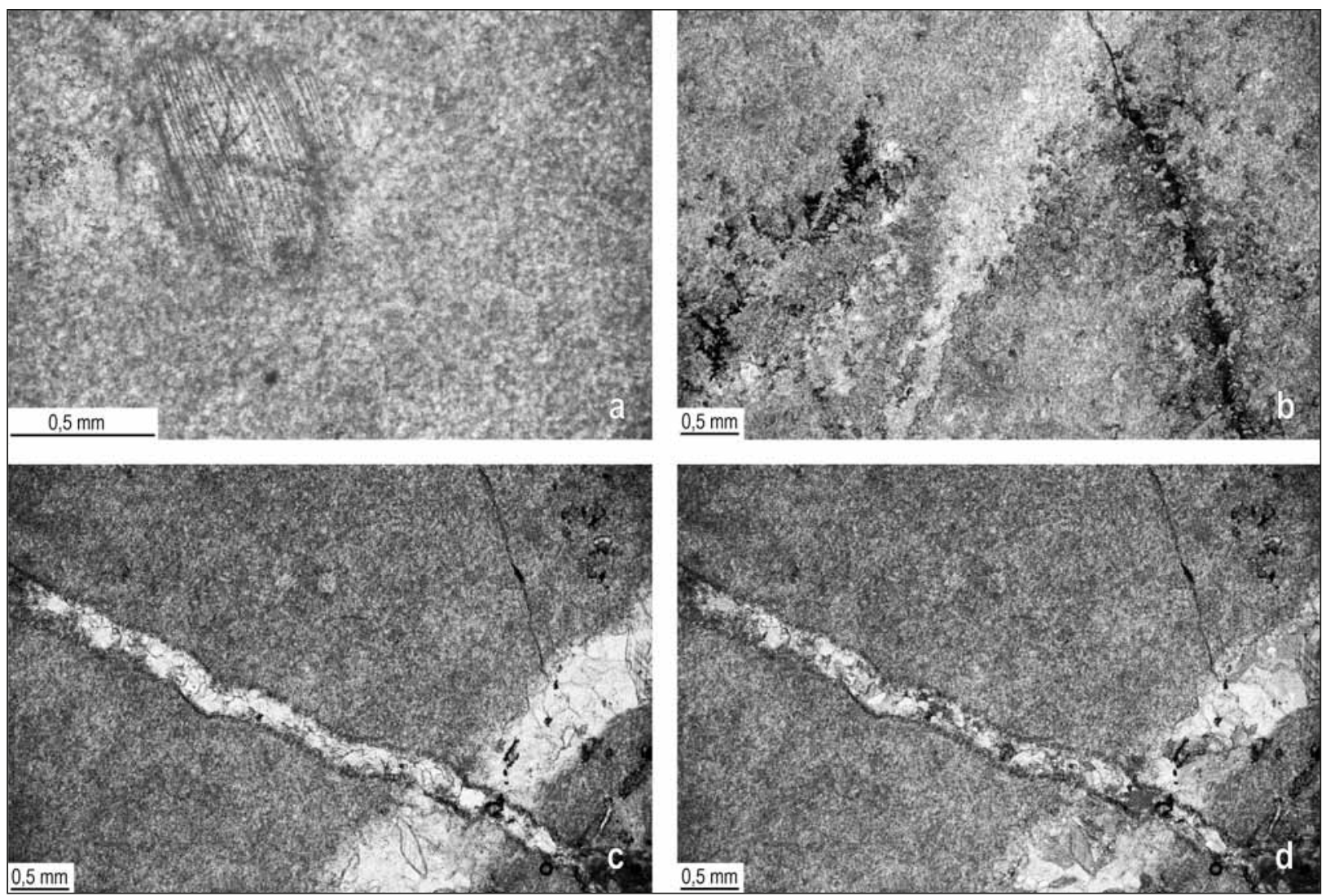

Obr. 2: a - Lamelovaný krystal kalcitu (úlomek ?článku lilijice) v mikrosparitu, PPL (světlo polarizované jedním nikolem); b - rozptýlené Fe-oxidy a (nebo) oxy-hydroxidy, PPL; c - vzorek 1 - žilky vyplněné hruběji krystalickým kalcitem, PPL; d - vzorek 1 - žilky vyplněné hruběji krystalickým kalcitem, XPL (světlo polarizované zkřriženými nikoly).

Fig. 2: a - The lamellae in calcite (fragment of ?crinoid article) in microsparite, PPL (Planar Parallel Light); b - Fe-oxides and (or) oxy-hydroxides, PPL; c - sample 1 - veins healed by coarsely crystalline calcite, PPL; $\mathrm{d}$ - sample 1 - veins healed by coarsely crystalline calcite, XPL. 
Studovaný devonský vápenec je velmi jemnozrnný a deformačně laminovaný. Má šedou barvu a praskliny vyhojené bílými žilkami kalcitu. Mikroskopicky se jedná o mikrosparitický vápenec. Místy se v hornině objevují větší krystaly kalcitu (úlomek? článku lilijice) dosahující až 1,2 mm, které vykazují mechanické dvojčatné lamelování (viz obr. 2a). Výplň žilek je tvořena krystaly hrubějšího sparitu (obr. 2c a 2d). Vedle dominujícího kalcitu jsou zde př́tomny i oxidy/oxy-hydroxidy železa (obr. 2b).

\section{Výsledky}

První a druhá série měření byla prováděna na různých vzorcích (1 a 4) a zároveň na dvou přístrojích s odlišnou geometrií. Přesto jsou dosažené výsledky srovnatelné. Byly změřeny intenzity difrakce následujících krystalografických ploch: (llll $\left.\begin{array}{lll}1 & 0 & 4\end{array}\right),\left(\begin{array}{lll}0 & 1 & 8\end{array}\right),\left(\begin{array}{lll}1 & 1 & 3\end{array}\right),\left(\begin{array}{lll}0 & 0 & 6\end{array}\right)$ a $\left(\begin{array}{lll}2 & 0 & 2\end{array}\right)$.

\section{Konvenční Brag-Brentano parafokusační uspořádání}

Difrakční maxima na záznamu kusového vzorku vápence č. 4 se shodovala s pozicemi difrakčních maxim kalcitu. Na záznamu je patrná přednostní orientace - poměry intenzit difrakčních maxim jsou odlišné od záznamu z databáze (PDF 2, číslo 98-015-8257) (viz obr. 3). Přehled dále studovaných strukturních rovin je uveden v tabulce 1 .

\section{Defokusační chyba}

Hodnoty intenzit pro roviny práškového vzorku křemene při daných úhlech $2 \theta$ jsou vyobrazeny v závislosti na změně úhlu náklonu $\alpha$ na obrázku 4. Ukazují lineární pokles intenzit při náklonu vyšším než $20^{\circ}$.

\section{Pólové obrazce}

Strukturní roviny ( 104$)$ na obrázku č. 5a vykazují nejvyšší intenzity v okolí středu, asymetrie se odráží vyššími intenzitami ve spodní části obrazce. Na obrázku č. 5b strukturní roviny (1 044$)$ vychází téměř symetricky $\mathrm{v}$ pravolevé ose s náklonem směrem do středu, a jsou tedy částečně protažené paralelně s měřenou plochou, která odpovídá foliaci.

Strukturní roviny $\left(\begin{array}{lll}0 & 1 & 8\end{array}\right)$ na obrázku č. $6 \mathrm{a}$ mají nejvyšší intenzity ve středu obrazce, slabě vychýlené od symetrie do spodní části obrazce. Strukturní roviny ( $\left.\begin{array}{lll}0 & 1 & 8\end{array}\right)$ na obrázku č. 6b vykazují po korekci asymetrickou orientaci směrem do středu, a to z horní poloviny obrazce. Roviny jsou tedy nakloněny na jednu stranu.

Strukturní roviny $\left(\begin{array}{lll}1 & 1 & 3\end{array}\right)$ na obrázku č. 7a mají intenzity po obvodu pólového obrazce, které odpovídají pravolevé ose symetrie. Na levé straně obrazce jsou vyšší intenzity. Strukturní roviny (1 113 ) na obrázku č. 7b vycházejí po korekci symetricky s intenzitami ve středu a hlavně po obvodu obrazce. To odpovídá vysokému úhlu náklonu vzhledem $\mathrm{k}$ měřené ploše a tedy $\mathrm{i} \mathrm{k}$ foliaci.

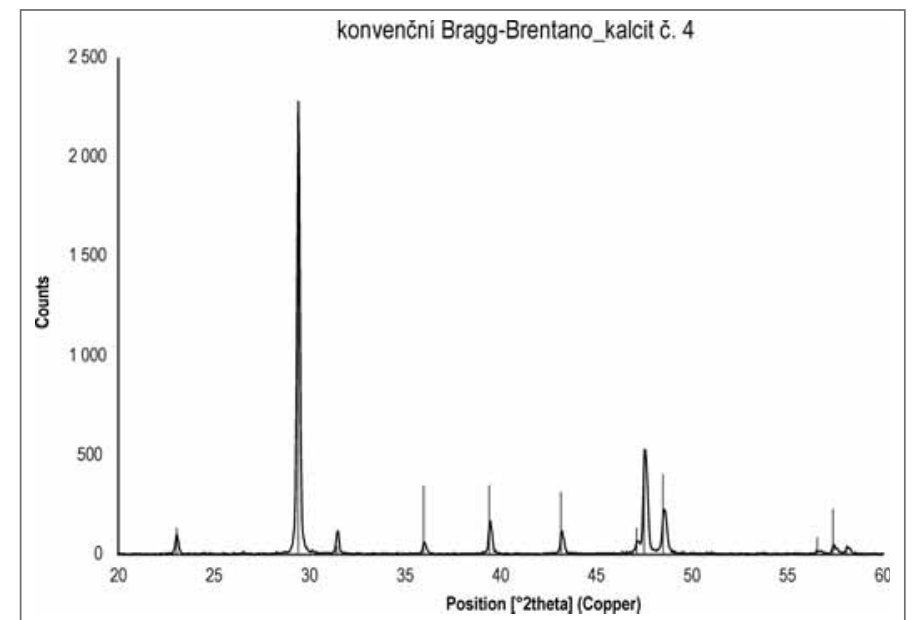

Obr. 3: Difrakční záznam vápence z lokality Vavřinec-Veselice (vzorek č. 4) s porovnáním poloh a intenzit difrakčních maxim kalcitu se vzorem kalcitu z databáze (hůlky odpovídají kalcitu z databáze).

Fig. 3: Difraction pattern of limestone from Vavřinec-Veselice (sample n. 4), which compares $2 \theta$ angle and intensities of diffraction maxima with database pattern of calcite (sticks shows the database pattern).

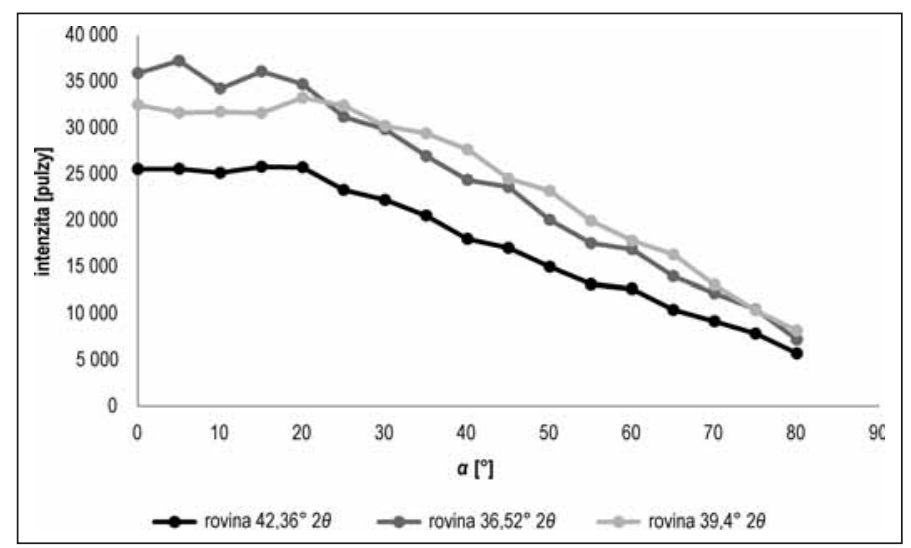

Obr. 4: Pokles naměřených intenzit difrakčních maxim práškového křemene v závislosti na úhlu náklonu vzorku.

Fig. 4: Decreasing of measured intensities of diffraction maxima of quartz powder sample according to the $\alpha$ angle.

Strukturní roviny (2 0 2 2) vycházejí stejně jako roviny (1 113 ), tedy s nejvyššími intenzitami po obvodu s mírnou asymetrií vyšších intenzit na levé straně obrazce.

Strukturní roviny ( $\left.\begin{array}{lll}0 & 0 & 6\end{array}\right)$ vyšly v prvním měření zcela asymetricky s intenzitami ve dvou bodech ve spodní části obrazce a jednom bodě v horní části obrazce. Ve druhém měření vyšly intenzity ve středu, mírně vychýlené do spodní části obrazce.

Pólové obrazce vynesené $\mathrm{z}$ dat $\mathrm{z}$ první série měření bez defokusační korekce mají nejvyšší intenzity ve středu, což je způsobené lineárním klesáním velikostí intenzit při naklonění vzorku o více než $20^{\circ}$.

Pólové obrazce různých krystalografických ploch obou vzorků vykazují zhruba rotační symetrii s mírně asymetrickými polohami intenzit. V první sérii měření (vzorek č. 4) jsou intenzity většiny měření $v$ obrazcích mírně posunuté $\mathrm{k}$ levé horní části do rozsahu $0^{\circ}<\beta<100^{\circ}$. U druhé série měření (vzorek č. 1) jsou intenzity posunuty na opačnou stranu $\mathrm{k} 160^{\circ}<\beta<250^{\circ}$, s výjimkou výsledků s intenzitami po obvodu obrazce. 


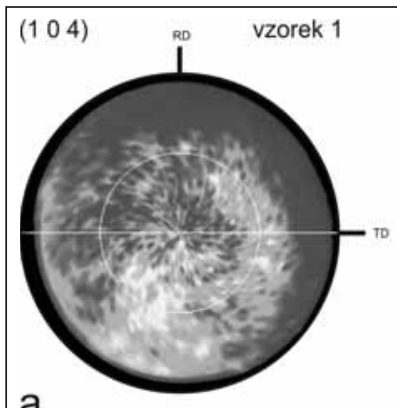

a

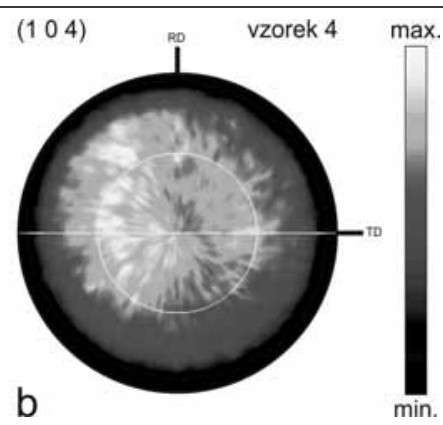

Obr. 5: Intenzity difraktovaného záření na studovaných vzorcích vápence pro rovinu (1 04 ): a - vzorek č. 1, měření v in-plane geometrii; b - vzorek č. 4, měření v Schulzově reflexní geometrii s provedenou defokusační korekcí. Stereografická projekce na horní polokouli.

Fig. 5: Diffraction intensities of limestone samples for crystallographic plane (1 0 4): a - sample n. 1, in-plane geometry; 5 - sample n. 4, Schulz reflection geometry with applied defocusing correction. Stereographic projection on the upper sphere.
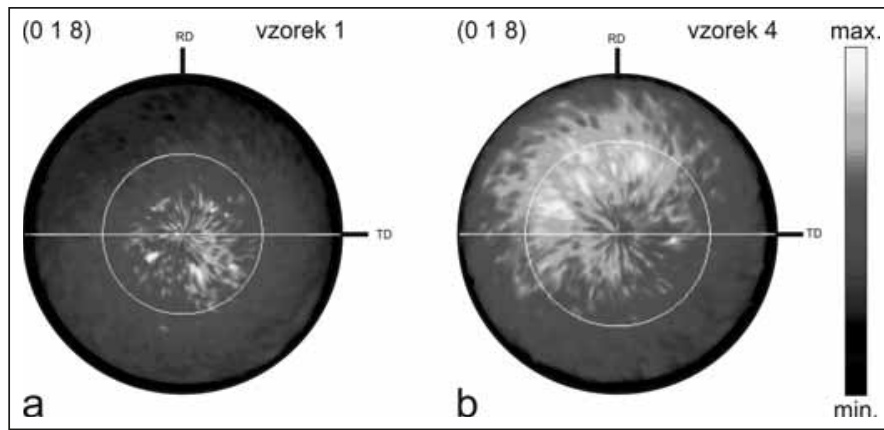

Obr. 6: Intenzity difraktovaného záření na studovaných vzorcích vápence pro rovinu (0 18 ): a - vzorek č. 1, měření v in-plane geometrii; b - vzorek č. 4 , měření v Schulzově reflexní geometrii s provedenou defokusační korekcí. Stereografická projekce na horní polokouli.

Fig. 6: Diffraction intensities of limestone samples for crystallographic plane (0 1 8): a - sample n. 1, in-plane geometry; b - sample n. 4, Schulz reflection geometry with applied defocusing correction. Stereographic projection on the upper sphere.

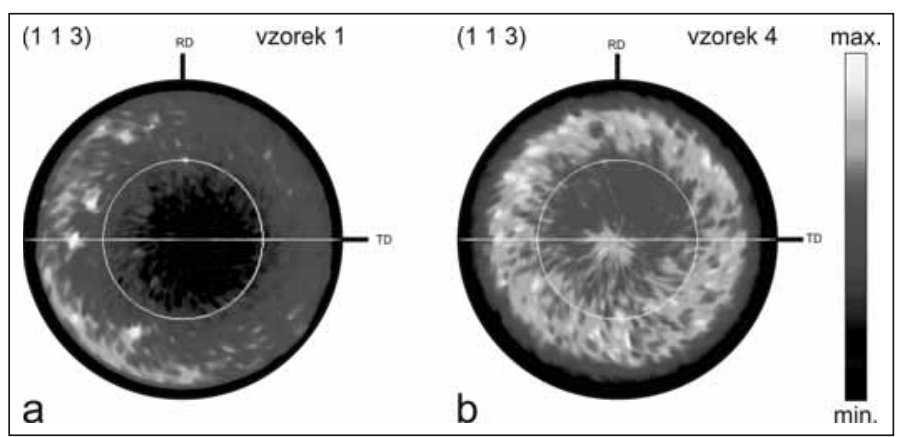

Obr. 7: Intenzity difraktovaného záření na studovaných vzorcích vápence pro rovinu (1 13 3): a - vzorek č. 1, měření v in-plane geometrii; b - vzorek č. 4 , měření v Schulzově reflexní geometrii s provedenou defokusační korekcí. Stereografická projekce na horní polokouli.

Fig. 7: Diffraction intensities of limestone samples for crystallographic plane ( $\left.\begin{array}{lll}1 & 1 & 3\end{array}\right)$ : a - sample n. 1, measurement of in-plane geometry; b - sample n. 4, measurement of Schulz reflection geometry with applied defocusing correction. Stereographic projection on the upper sphere.

\section{Diskuze}

Výsledky ukazují, že krystality kalcitu jsou přednostně orientovány a že roviny s nejintenzivnějšími difrakčními maximy (lllll $\left.\begin{array}{lll}0 & 4\end{array}\right)$ a $\left(\begin{array}{lll}0 & 1 & 8\end{array}\right)$ jsou natočeny přibližně paralelně s plochou foliace, tedy s rovinou střihu. To je $\mathrm{v}$ souladu s pozorováním intenzit difrakce pro roviny $\left(\begin{array}{lll}1 & 1 & 3\end{array}\right)$, které mají maxima po obvodu obrazce. Stejně tak přednostní orientaci ploch $\left(\begin{array}{lll}0 & 1 & 8\end{array}\right)$ rovnoběžně s foliací odpovídá i př́čná pozice $\left(\begin{array}{lll}2 & 0 & 2\end{array}\right) \mathrm{s}$ maximy intenzit podél obvodu diagramu. Rovina ( $\left.\begin{array}{lll}0 & 0 & 6\end{array}\right)$ byla označena za chybné měření.

Dominující přednostní orientace ploch štěpnosti podél plochy foliace potvrzuje souvislost ploch deformačního střihu s rovinami štěpnosti klence ( $\left(\begin{array}{lll}1 & 0 & 4\end{array}\right)$ a rovinami nižšího klence $\left(\begin{array}{lll}0 & 1 & 8\end{array}\right)$ a zároveň to dokládá uplatnění kataklastického toku jako hlavního mechanismu deformace hornin, kdy se kombinovalo drcení po plochách štěpnosti a prokluz po hranicích zrn.

U většiny pólových obrazců se projevila mírná asymetrie oproti rotační nebo kosočtverečné deformační symetrii, která může být způsobena řadou faktorů, jako například nehomogenitami ve vzorku (fosilie a jiné zbytky nerekrystalizované při deformaci, a tedy s nižší symetrií). I když nelze vyloučit vliv primárních nehomogenit, mohly by zjištěné mírné asymetrie obrazců být důsledkem nižší (jednoklonné) symetrie deformace jednoduchým stř̌ihem. Zároveň v závislosti na původu asymetrie ( $\mathrm{S}-\mathrm{C}$ stavba, p-střihy) by tato asymetrie mohla ukazovat směr tektonického pohybu nadloží. S tím souvisí otázka vysvětlení asymetrie přednostní orientace $\mathrm{v}$ diagramech. Měření roviny $\left(\begin{array}{lll}1 & 0 & 4\end{array}\right)$ v první sérii ukázalo asymetrii odpovídající mechanismu p-střihů, zatímco ve druhé sérii měření by asymetrie obrazce intenzit difrakce roviny $\left(\begin{array}{lll}1 & 0 & 4\end{array}\right)$ implikovala spíše mechanismus vzniku S-C-C' struktury. Vzhledem k malému počtu studovaných vzorků je nutno tuto otázku nechat otevřenu.

\section{Závěr}

Cílem práce bylo ověřit využití texturní retngenové difrakční analýzy pro studium tektonicky postižených hornin, u kterých není možné kvantifikovat přednostní orientaci krystalů běžnými optickými metodami, a rozšírít tak tuto metodu v geologické praxi. Byly odebrány vzorky jemnozrnných hornin, u kterých bylo možné na výchoze určit smysl tektonického pohybu, který byl korelován se získanými daty rentgenového měření. Výsledky ve formě pólových obrazců ukazují na mechanismus deformace, který byl určen jako kataklastický tok, na základě natočení ploch štěpnosti klence vůči plochám foliace. Metodou je tedy možné určit mechanismy porušení hornin. Výsledky vykazují mírné asymetrie, které mohou poukazovat na smysl tektonického pohybu, ale mohou být také způsobeny nehomogenitami ve vzorcích. Pro další studium 
by bylo třeba určit, jakým způsobem nehomogenity ovlivñují symetrie pólových obrazců.

\section{Poděkování}

Autor tímto děkuje za umožnění provedení RTG-difrakčních experimentů projektu CEITEC - open access project, ID number LM2011020 a Ing. Pavle Roupcové, Ph.D., za di̊sledné provedení odborné recenze.

\section{Literatura}

Gross, R. (1920): Erweiterte Lauemethode. - Centralblatt für Mineralogie, Geologie und Paläontologie, 120, 52-64, Stuttgart. Marhanský, T. (2014): Násunová stavba na styku brněnského masivu a paleozoických sedimentů severní části Moravského krasu. - MS, diplomová práce. Př́rodovědecká fakulta Masarykovy univerzity. Brno.

Nagao, K. - Kagami, E. (2011): X-ray thin film measurement techniques. - The Rigaku Journal, 27, 2, 6-13, Tokio.

Schmidt, J. (1975): Rentgenografické metody studia vnitřní stavby hornin. - Folia Facultatis Scientiarum Naturalium Universitatis Purkynianae Brunensis, 16, 8, 1-87, Brno.

Štelcl, J. - Beneš, K. - Pták, J. (1980): Základy drobné tektoniky a petrotektoniky. - Univerzita J. E. Purkyně, Brno.

Wever, F. (1924): Über die walzstruktur kubish kristallisierender metalle. - Zeitschrift für physik, 28, 69-90, Berlín. 